\title{
近位尿道の交感神経系支配に関する研究
}

\author{
秋田大学医学部泌尿器科学教室 西沢理
(主任:土田正義教授)
}

\section{STUDIES ON THE AUTONOMIC INNERVATION OF THE PROXIMAL URETHRA IN THE FEMALE DOG}

\author{
Osamu Nishizawa \\ Department of Urology, Akita University School of Medicine
}

(Director: Prof. S. Tsuchida)

To investigate the action of the autonomic nerves on the proximal urethra, isovolumetric pressure response to electrical hypogastric and pelvic nerve stimulations in the proximal urethra of the female dog was examined in control conditions and after administration of several autonomic blocking agents. The hypogastric nerve was transected just distal to the inferior mesenteric ganglia and the pelvic nerve was transected just proximal to the pelvic plexus. Both nerves were stimulated with bipolar stimulating electrodes (MT. Technical Research Co.) placed at the distal end of the transected nerves.

Hypogastric and pelvic nerve stimulations produced contraction of the proximal urethra. Proximal urethral contraction responses to hypogastric nerve stimulation were blocked by administration of phentolamine and guanethidine, and not influenced by administration of propranolol and hexamethonium. These contraction responses seem to be mediated through the long postganglionic adrenergic fibers which arise from the inferior mesenteric ganglia. Proximal urethral contraction responses to pelvic nerve stimulation were blocked by administration of phentolamine, guanethidine and hexamethonium, and not influenced by administration of propranolol. These contraction responses seem to be mediated through the short postganglionic adrenergic fibers which arise from the intramural ganglia.

These experimental results suggest that adrenergic fibers play an important roll in the resting wall tension of the proximal urethra.

\footnotetext{
要旨: 交感神経系の近位尿道に対する作用を明らかにする目的で, 雌の雑種成犬を対象とし各種自律神経遮断 剂 ( $\alpha$ 型遮断薬 : phentolamine, $\beta$ 型遮断薬 : propranolol, アドレ゙ナリン作働性ニューロン遮断薬 : guanethidine，神経節遮断薬 : hexamethonium）の投与前後に拈いて下腹および骨盤神経電気刺激に対する近位尿道 の反応について検討した。下腹神経は下腸間膜動脈神経叢の末梢側で，骨盤神経は骨盤神経叢の中枢側で切断 し，その切断末梢端にスライド式刺激電極（MT 技研）を装着して刺激を行つた.

近位尿道はその反応を isovolumetric pressure で把えると，下腹および骨盤神経電気刺激のいずれに対しこ も収縮反応を示した。下腹神経電気刺激に対する近位㽷道の収縮反応は phentolamine および guanethidine の投与により抑制を受け，propranolol および hexamethonium の投与では不変であつた。したがつて，この 収縮反応は下腸間膜動脈神経叢にてニューロンをかえた long postganglionic adrenergic fiber を介して生じた ものと考えられた。一方，骨盤神経電気刺激に対する近位尿道の収縮反応は phentolamine，guanethidine お よび hexamethonium の投与により抑制を受け，propranolol の投与では不変であつた。したがつて，この収 縮反応は壁内神経節でニューロンをかえて尿道に分布する short postganglionic adrenergic fiber を介して生 じたものと考えられた．以上の結果は近位尿道の壁緊張に対する adrenergic fiber の重要性を示唆するもので ある・
}

\section{緒 言}

最近, 近位尿道（proximal urethra）は蓄尿作用（con- tinence) を受け持つ部分としてその作用発現のメカニ ズムが注目されている，近位尿道の平滑筋層にはアドレ 
ナリン持よびコリン作働性神経終末の存在が多数認めら れていることから ${ }^{1) \sim 5)}$, 交感扣よび副交感神経は近位尿 道の機能に重要な役割を果しているものと思われる. 下 腹神経内の交感神経性線維の役割は, これまでの研究か ら $\alpha$ 受容体を介して尿道壁に固有の緊張を与えるとする 説が多(6) 15). しかし, 骨盤神経内 の副交感神経性線 維の尿道に対する作用に関しては不明の部分が多く, ま た, 交感, 副交感神経の末梢レベルでの相互関係や両者 の機能的分担なども解明されていない.

このような諸点がなお不明のままに留つている扔もな 理由は, 従来の実験方法に難点があつたためと思われ る.すなわち，これまでの下腹および骨盤神経電気刺激 に対する近位尿道の反応に関する報告(6)12) 18)をみると， 大部分の実験が膀腃と尿道との連絡を保つたままで行わ れている.このような方法では Awad \& Downie ${ }^{12)}$ お よび McGuire ${ }^{15)}$ も指摘しているように, 神経刺激に対 する尿道の反応がこの刺激により同時に起る膀腃の反応 の中に鿵されてしまう可能性がある.

一方，検查法自体についてみると海流告 ${ }^{12) 13115) 16)}$ ある いはバルンカテーテル 14)17)18) で尿道内圧を測定する方法 が行われているが，前者は定量性に乏しく，後者はバル ンを設置した特定部位の反応を捉えることはできるが， 近位尿道の全体的な反応は捉光難いといら久点がある.

このような諸点を反省して，私は尿道内圧の測定にあ たり，尿道反応に対する膀胱の影響を除外するために膀 胱体部を切除し, 膀腃の反応が尿道に及ばない実験法を 考案した. そして，下腹扣よび骨盤神経電気刺激に対す る近位尿道全体の反応を isovolumetric pressure として 測定し，これに対する自律神経遮断剤の影響を検討し た. この実験方法を用いて骨盤神経支配の問題について 2,3 の興味ある知見を得たので報告する。

\section{実験対象および方法}

実験対象としては体重7〜14kg の雌の雑種成犬 28 頭を 使用し, 実験は pentobarbital 25 30 mg/kg 麻酔下で行 つた．呼吸は気管切開部から挿入した気管チューブを介 して行わせ, このチューブに $1 / \mathrm{min}$ の酸素を流した. 近位尿道内圧の測定 : 腹部正中切開で尿管, 膀胱扣よ び尿道を露出した．まず，尿を膀脱に詝留することなく 直接体外飞誘導するために, 雨側尿管を尿管膀脱移行 部より約 $6 \mathrm{~cm}$ 上方で切断し, 腎孟側切断端より $4 \mathrm{Fr}$. カ テーテルを尿管内に搟入した。 そして，このカテーテル の他端を腹壁を通して, 体外飞導いた. 近位尿道内圧測 定には $10 \mathrm{Fr}$. カテーテルを外尿道口から尿道内挿入
し，その先端が膀胱頝部と尿生殖隔膜との中間部にある ようにした.この際, 膀胱䅡部に粘膜下币着縫合を和き， さらにカテーテル先端部位の $0.5 \sim 1 \mathrm{~cm}$ 末梢側 の 尿道 周囲に 1 号綟系を通して, 尿道を結紮して近位尿道全体 を1つの閉鎖された内腔とした．そして，この内腔に生 理的食塩水を満たして isovolumetric pressure を測定で きるようにした，最後に，骨盤神経叢から膀胖へ至る神 経走行を充分確認し本幹に関しては損傷を与えないよう に膀胼三角部のみを残して膀胱体部を切除し, 膀脱収縮 が近位尿道内圧に影響しないようにした。内压の記録は 日本光電製ポリグラフ（RM 6000）を使用した.

神経刺激：下腸間膜動脈神経叢の $1 \sim 2 \mathrm{~cm}$ 末梢側で 両側下腹神経を露出, 切断し, さらに骨盤神経叢より $2 \sim 3 \mathrm{~cm}$ 中枢側で两側骨盤神経を露出し, 切断した.下 腹神経の電気刺激に対する反応をみる場合には，スライ ド式刺激電極（MT 技研）を下腹神経切断未梢端に装 着し, 電気刺激を行つた. 同椂に骨盤神経の電気刺激に 対する反応を検討する場合にも，電極を骨盤神経切断末 梢端に装着して行つた. 同一対象について下腹执よび骨 盤神経雨者の電気刺激に刘する反応を検討する場合は, それぞれの神経の切断末梢端に電極を装着して刺激を行 つた.この場合, 刺激の順序は下腹神経, 続いて骨盤神 経の順に, 最低 5 分間の間隔を沶いて実施した。刺激条 件は De Sy ら ${ }^{19)}$ の報告に従い, $5 \mathrm{~V}, 20 \mathrm{~Hz}, 2 \mathrm{msec}$ とし, 持続時間は 10 秒間とした。神経電気刺激には日本光電製 電気刺激装置 (SEN-7103) を用いた（図 1).

使用薬剂抢よび投与方法 : $5 \mathrm{Fr}$. カテーテルを大腿静 脈に挿入し，これを通じて $5 \mathrm{ml}$ の生理的食塩水に溶解 して薬剂を注入した. 使用した自律神経遮断剂は $\alpha$ 型遮 断薬: phentolamine (Regitine, 日本チバガイキー), $\beta$ 型遮断薬 : propranolol (Inderal, 住友化学工業), アドレ ナリン作働性ニューロソ遮断薬 : guanethidine (Ismelin, 日本チバガイギー), 神経節遮断薬 : hexamethonium (Methobromin，山之内製薬) の 4 種類である.

薬剂の効果の観察：まず，投与前の電気刺激に対する 尿道内圧反応を対照として観察した。次に薬剤を注入 し, 注入終了後に電気刺激を行い, 得られた尿道内圧反 応を投与後の反応とした. propranolol 以外の 3 種の薬 剤については初回投与の反応を観察した後, 同量の追加 投与を行い，これに対する反応についても観察した。 そ して, 各々の薬剤投与前後に拈いて収縮反応圧（電気刺 激により惹起された尿道内圧の最高值と刺激開始值前の 尿道静止圧との差）を測定し，その測定值について $\mathrm{t}$ 検 
図 1 実験方法略図

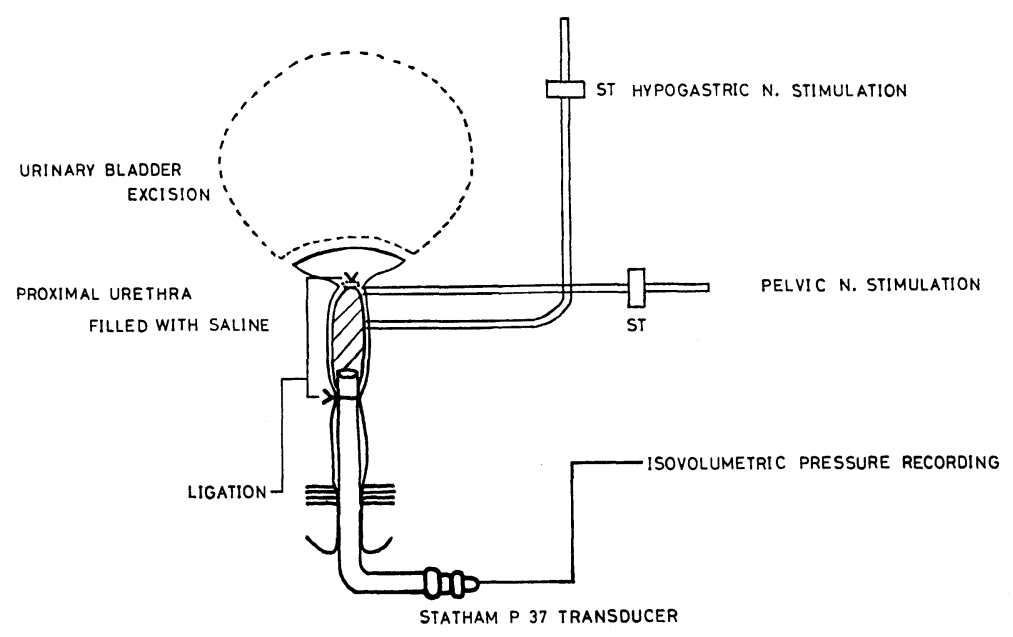

定により推計学的検討を行つた.

以上の実験中, 営径部股動脈から中权側に向つて $5 \mathrm{Fr}$. の尿道静止圧は全例の薬剤投与前後においてほぼ一定で あつた。

カテーテルを挿入し，動脈圧を同時に記録した。この場 合も前述した日本光電製 ポリグラフを使用した. そし て, 電気刺激開始直前の収縮期血圧と払張期血圧との平 均値を測定し，その測定值に関しても薬阂投与前後にお いて $\mathrm{t}$ 検定により推計学的検討を行つた。

\section{実験成績}

下腹括よび骨盤神経電気刺激例に括ける phentolamine, propranolol, guanethidine, hexamethonium が近位 尿道の収縮反応圧扣よび血圧に及ぼす影響を観察した成 績を一括して表 1，2 亿示す.なお, 神経刺激開始直前

表 1 下腹神経電気刺激に上る収縮反応圧および血圧に対する各種遮断剤の効果

\begin{tabular}{|c|c|c|c|c|}
\hline 各楽剂投与群 & 投与量 & 収縮反応圧 & $(\mathrm{mmHg})$ & 血圧 $(\mathrm{mmHg})$ \\
\hline \multirow{3}{*}{$\begin{array}{l}\text { Phentolamine } \\
\qquad(n=6)\end{array}$} & Control & $7.71 \pm 0.88$ & & $94.50 \pm 7.92$ \\
\hline & $0.25 \mathrm{mg} / \mathrm{kg}$ & $2.38 \pm 0.16$ & $\mathrm{p}<0.005$ & $103.33 \pm 6.01 \mathrm{NS}$ \\
\hline & $0.50 \mathrm{mg} / \mathrm{kg}$ & $1.18 \pm 0.39$ & $\mathrm{p}<0.005$ & $81.50 \pm 9.96 \mathrm{NS}$ \\
\hline \multirow{2}{*}{$\begin{array}{l}\text { Propranolol } \\
\qquad(\mathrm{n}=7)\end{array}$} & Control & $6.71 \pm 0.95$ & & $112.50 \pm 6.24$ \\
\hline & $0.50 \mathrm{mg} / \mathrm{kg}$ & $10.10 \pm 1.65$ & NS & $99.64 \pm 4.10 \mathrm{NS}$ \\
\hline \multirow{3}{*}{$\begin{array}{l}\text { Guanethidine } \\
\quad(n=6)\end{array}$} & Control & $4.86 \pm 0.43$ & & $91.67 \pm 8.23$ \\
\hline & $2.50 \mathrm{mg} / \mathrm{kg}$ & $2.50 \pm 0.52$ & $\mathrm{p}<0.025$ & $94.17 \pm 14.74 \mathrm{NS}$ \\
\hline & $5.00 \mathrm{mg} / \mathrm{kg}$ & $0.63 \pm 0.31$ & $\mathrm{p}<0.005$ & $145.42 \pm 15.20 \mathrm{p}<0.025$ \\
\hline \multirow{3}{*}{$\begin{array}{l}\text { Hexamethonium } \\
\qquad(n=6)\end{array}$} & Control & $5.50 \pm 0.94$ & & $116.00 \pm 5.34$ \\
\hline & $5.00 \mathrm{mg} / \mathrm{kg}$ & $4.00 \pm 0.98$ & NS & $77.00 \pm 6.63 \quad \mathrm{p}<0.005$ \\
\hline & $10.00 \mathrm{mg} / \mathrm{kg}$ & $4.30 \pm 0.79$ & NS & $76.88 \pm 6.72 \quad p<0.005$ \\
\hline
\end{tabular}

mean $\pm \mathrm{SE}, \mathrm{NS}:$ not significant

a. 下腹神経電気刺激

1) phentolamine

対照として薬剂投与前に両側下腹神経の電気刺激を行 つた場合に拈ける近位尿道内圧の変化についてみる.下 腹神経を 10 秒間刺激すると, 近位尿道内圧は上昇し, 刺 激終了とほぼ同時に下降に移り, やがて刺激前の内圧ま で低下する. phentolamine 投与下に刺激を行うと, 近 位尿道内圧は 6 例全例に沶いて図 2 のよらな変化を呈 し，投与前に認められた収縮反応は抑制される傾向を示 した. 
表 2 骨盤神経電気刺激による収縮反応圧および血圧に対する各種遮断剤の効果

\begin{tabular}{|c|c|c|c|}
\hline 各薬剤投与群 & 投与量 & 収縮反応王 $(\mathrm{mmHg})$ & 血圧（mmHg） \\
\hline \multirow{3}{*}{$\begin{array}{l}\text { Phentolamine } \\
\quad(n=14)\end{array}$} & Control & $5.84 \pm 0.94$ & $100.00 \pm 4.85$ \\
\hline & $0.25 \mathrm{mg} / \mathrm{kg}$ & $2.81 \pm 0.77 \quad \mathrm{NS}$ & $97.00 \pm 6.82 \quad$ NS \\
\hline & $0.50 \mathrm{mg} / \mathrm{kg}$ & $1.16 \pm 0.34$ & $83.64 \pm 5.57$ \\
\hline \multirow{2}{*}{$\begin{array}{l}\text { Propranolol } \\
\qquad(n=4)\end{array}$} & Control & $4.56 \pm 1.34$ & $105.00 \pm 5.40$ \\
\hline & $0.50 \mathrm{mg} / \mathrm{kg}$ & $6.94 \pm 2.05 \mathrm{NS}$ & $97.50 \pm 5.20 \quad \mathrm{NS}$ \\
\hline \multirow{3}{*}{$\begin{array}{l}\text { Guanethidine } \\
\quad(n=9)\end{array}$} & Control & $5.31 \pm 1.20$ & $91.94 \pm 5.43$ \\
\hline & $2.50 \mathrm{mg} / \mathrm{kg}$ & $2.87 \pm 1.02 \quad \mathrm{NS}$ & $106.43 \pm 9.62 \mathrm{NS}$ \\
\hline & $5.00 \mathrm{mg} / \mathrm{kg}$ & $0.93 \pm 0.54 \quad p<0.005$ & $133.57 \pm 16.10$ \\
\hline \multirow{3}{*}{$\begin{array}{l}\text { Hexamethonium } \\
\quad(n=7)\end{array}$} & Control & $5.87 \pm 0.89$ & $119.17 \pm 6.64$ \\
\hline & $5.00 \mathrm{mg} / \mathrm{kg}$ & $3.38 \pm 0.99 \quad \mathrm{NS}$ & $77.50 \pm 4.79 \quad \mathrm{p}<0.005$ \\
\hline & $10.00 \mathrm{mg} / \mathrm{kg}$ & $2.69 \pm 0.88 \quad \mathrm{p}<0.05$ & $73.33 \pm 4.41 \quad \mathrm{p}<0.005$ \\
\hline
\end{tabular}

mean $\pm \mathrm{SE}, \mathrm{NS}$ : not significant

図 2 phentolamine投与前後にお汀る下腹神経電気刺激に対する尿道収縮反応の変化： phentolamine $0.25 \mathrm{mg} / \mathrm{kg}, 0.5 \mathrm{mg} / \mathrm{kg}$ の投与により，神経刺激に対する近位尿道収縮 反応は抑制されている。

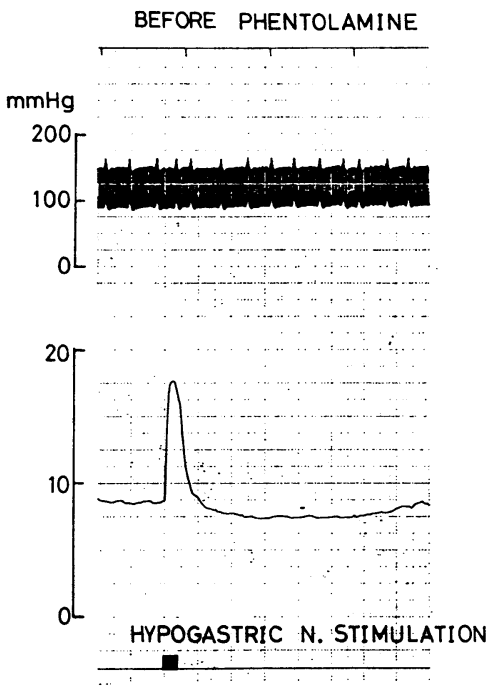

近位尿道の収縮反応圧および血圧の 測定值について 推計学的に検討すると，収縮反応圧は phentolamine 投 与後には投与前と比較し，有意に低下を示した $(\mathrm{p}<$ 0.005)。また，血圧には有意差が認められなかつた（表 $1)$.

2) propranolol

propranolol 投与下に刺激を行うと, 近位尿道内圧は 7 例全例に和いて図 3 のような变化を呈し，收縮反応は
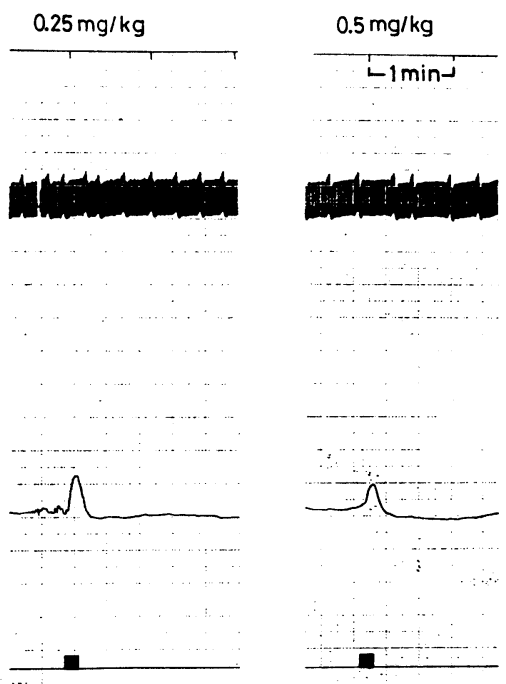

軽度ながら增強される傾向を示した．しかし，推計学的 に検討すると，収縮反応圧および血圧は propranolol 投 与後では投与前と比較して有意の变化を示さなかつた (表 1).

3) guanethidine

guanethidine 投与下に刺激を行うと, 近位尿道内压は 6 例全例に执いて図4のような変化を呈し，収縮反応は 抑制される傾向を示した，推計学的に検討すると，収縮 
㘠 3 propranolol 投与前後に拈ける下腹神経電気刺激に対与る尿道収縮反応の変化: propranolol $0.5 \mathrm{mg} / \mathrm{kg}$ の投与により, 神経刺激に対する近位尿道収縮反応は軽度なが ら增強されている。
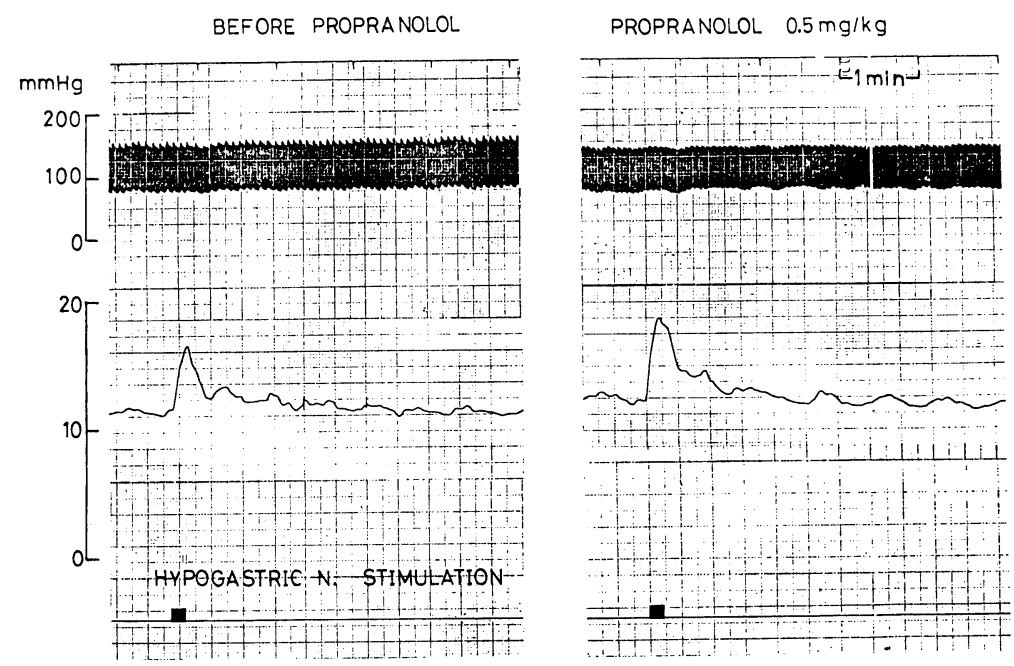

図 4 guanethidine 投与前後における下腹神経電気 刺激に対する尿道収縮反応の変化: guanethidine $2.5 \mathrm{mg} / \mathrm{kg}, 5 \mathrm{mg} / \mathrm{kg}$ の投与により，神経刺激に対 する近位尿道収縮反応は抑制されている。
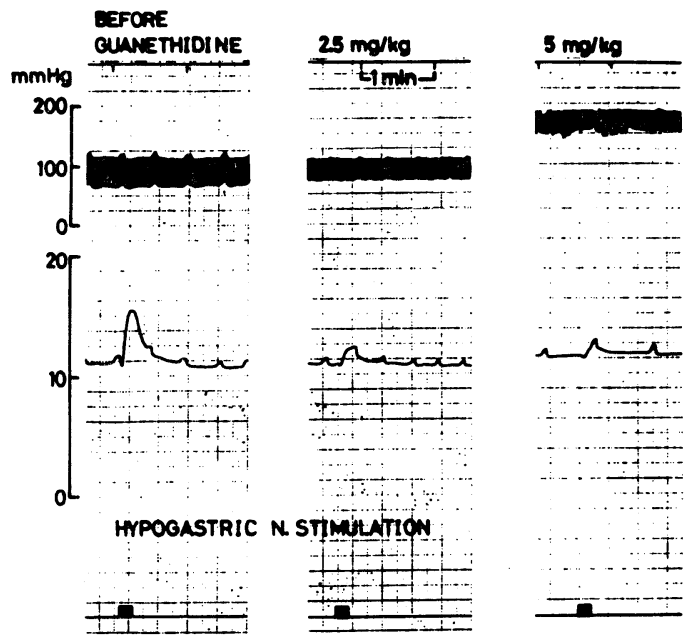

反応死は guanethidine $2.5 \mathrm{mg} / \mathrm{kg}$ 投与後には投与立ijと比 較して有意に低下を示した $(\mathrm{p}<0.025)$ ，また，血圧に は有意差が認められなかつた. $5 \mathrm{mg} / \mathrm{kg}$ 投与後では収縮 反応珐は有意に低下を示し $(p<0.005)$, 一方，血圧は 有意に上昇を示した $(\mathrm{p}<0.025$ ，表 1$)$.

4) hexamethonium

hexamethonium 投与下に刺激を行うと，近位㽷道内
圧は 6 例全例において図 5 のような変化を呈し, 収縮反 応は軽度ながら抑制される傾向を示した。しかし，推計 学的に検討すると, 収縮反応圧は hexamethonium 投与 後には投与前と比較して有意の変化を示さなかつた。 ま た，血圧は有意に低下を示した（p>0.005，表 1$)$.

b. 骨盤神経電気刺激

1) phentolamine

薬剂投与前に骨盤神経電気刺激を行つた際の近位尿道 内圧の変化は，下腹神経の場合と同様な pattern で，収 縮反応を示した. phentolamine 投与下に刺激を行うと, 近位尿道内圧は14例全例に拈いて図6のような変化を 呈し，収縮反応は抑制される傾向を示した，推計学的 に検討すると, 収縮反応圧および血圧は phentolamine $0.25 \mathrm{mg} / \mathrm{kg}$ 投与後では投与前と比較して有意の変化を 示さなかつた. $0.5 \mathrm{mg} / \mathrm{kg}$ 投与後では収縮反応圧は有意 に低下を示し $(\mathrm{p}<0.005)$ ，血圧も有意に低下を示した $(\mathrm{p}<0.05$ ，表 2$)$.

2) propranolol

propranolol 投与下に刺激を行うと, 近位尿道内圧は 4 例全例に揖いて図 7 のよらな変化を呈し，収縮反応は 軽度ながら增強される傾向を示した。しかし，推計学的 に検討すると，収縮反応圧扣よび血圧は propranolol 投 与後には投与前と比較して，有意の変化を示さなかつた （表 2).

3) guanethidine 
図 5 hexamethonium 投与前後における下腹神経電気刺激に対する尿道収縮反応の変化: hexamethonium $5 \mathrm{mg} / \mathrm{kg}, 10 \mathrm{mg} / \mathrm{kg}$ の投与により，神経刺激に対する近位尿道収縮反応は 軽度ながら抑制されている。
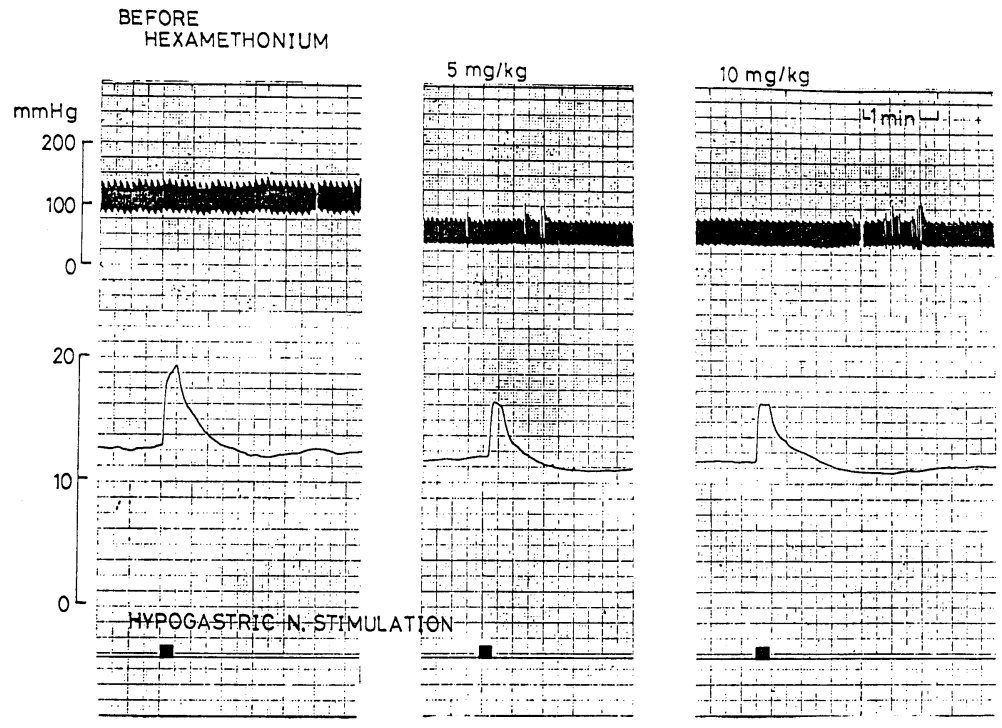

図 6 phentolamine 投与前後に打ける骨盤神経電気刺激に対する尿道取縮反応の変化: phentolamine ${ }_{\text {ik }}^{r} 0.25 \mathrm{mg} / \mathrm{kg}, 0.5 \mathrm{mg} / \mathrm{kg}_{\mathrm{z}}^{\nabla}$ の投与により，神経刺激に対する近位尿道収縮 反応は抑制されている。

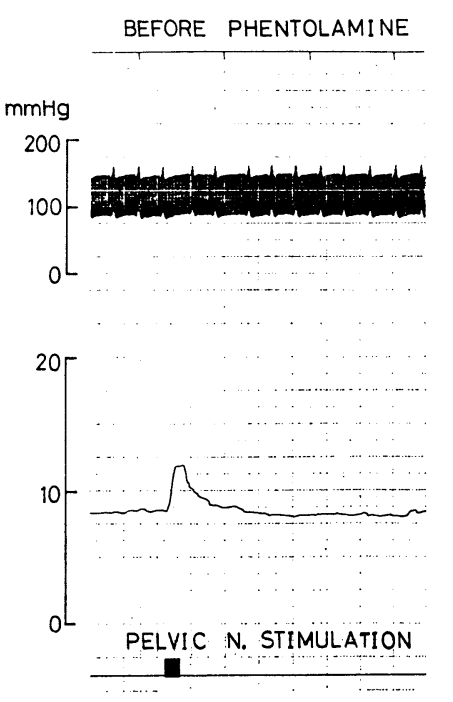

guanethidine 投与下に刺激を行うと，近位尿道内圧は 9 例全例に和いて図 8 のような変化を呈し，収縮反応は 抑制される傾向を示した，推計学的に検討すると，収縮 反応圧および血圧は guanethidine $2.5 \mathrm{mg} / \mathrm{kg}$ 投与後に は投与前と比較して，有意の変化を示さなかつた。 5
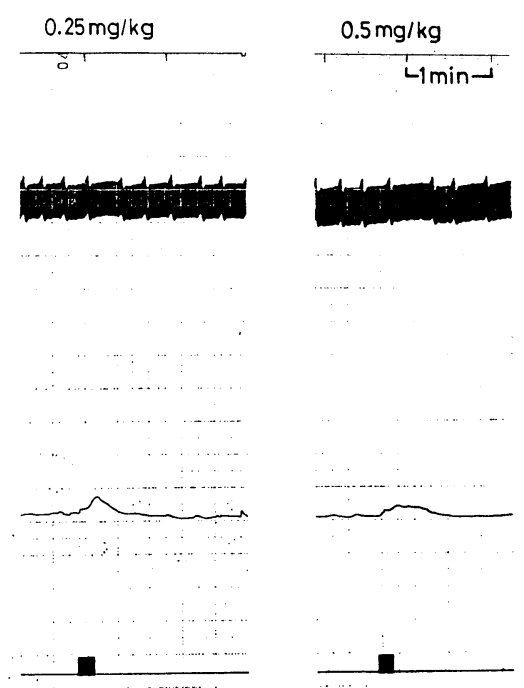

$\mathrm{mg} / \mathrm{kg}$ 投与後では収縮反応圧は有意に低下を示し $(\mathrm{p}<$ $0.005)$ ，一方，血圧は有意に上昇を示した（ $\mathrm{p}<0.025$ ， 表 2 ).

4) hexamethonium

hexamethonium 投与下に刺激を行うと，近位尿道内 
図 7 propranolol 投与前後にお汀る骨盤神経電気刺激に対する尿道収縮反応の変化： propranolol $0.5 \mathrm{mg} / \mathrm{kg}$ の投与により，神経刺激に対する近位尿道収縮反応は軽度なが ら増強されている。

BEFORE PROPRANOLOL

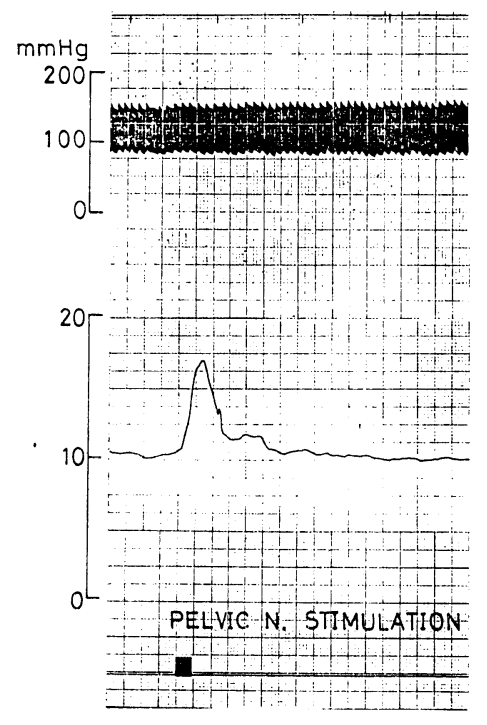

PROPRANOLOL $0.5 \mathrm{mg} / \mathrm{kg}$

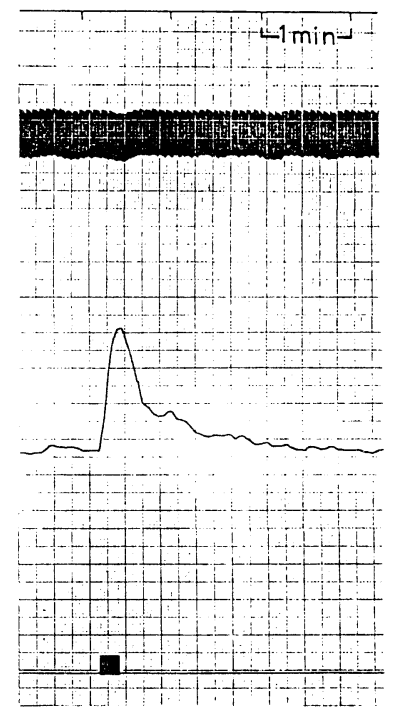

表 3 下腹および骨盤神経刺激に対する近位尿道収 縮反応へ及ぼす薬剂の効果

\begin{tabular}{l|c|c}
\hline & $\begin{array}{c}\text { 下腹神経刺激に } \\
\text { 対学盤神経刺激に }\end{array}$ \\
\hline phentolamine & 抑 制 & 抑 制 \\
\hline propranolol & 不 変 & 不 変 \\
\hline guanethidine & 抑 制 & 抑 制 \\
\hline hexamethonium & 不 変 & 抑 制 \\
\hline
\end{tabular}

意に低下を示した $(p<0.005) .10 \mathrm{mg} / \mathrm{kg}$ 投与後では仪

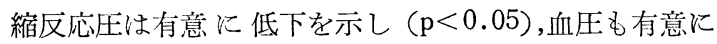
低下を示した $(\mathrm{p}<0.005$ ，表 2$)$.

以上から，本実験で薬剤投与前に諗められた下腹，骨 盤神経刺激による近位尿道収緶反応注対する各種自律 神経遮断剤の作朋は，表 3 のようにまとめることができ る.

\section{考案}

本実験モデルを作るにあたつて私が工夫したのは次の 2 点である。すなわち，第 1 は下腹および骨盤神経電気 刺激に伴う膀脱収縮が尿道内圧に影響を及ぼさぬ上ら膀 椸体部を切除した点であり，第 2 は尿道内压を isovolu metric pressure として测定した点である。第1点関

\footnotetext{
しては膀胱前壁の切開開放や太いチューブの膀胱内挿入
}

圧は7 例全例において図 9 のような変化を呈し, 収縮反 応は抑制される傾问を示した. 推計学的に検討すると, 収縮反忘压は hexamethonium $5 \mathrm{mg} / \mathrm{kg}$ 投与後では掞与. 前と比較して, 有意の変化を示さなかつたが，血圧は有 
図 9 hexamethonium投与前後における骨盤神経電気刺激に対する尿道収縮反応の変化： hexamethonium $5 \mathrm{mg} / \mathrm{kg}, 10 \mathrm{mg} / \mathrm{kg}$ の投与により，神経刺激に対する近位尿道収縮反応 は抑制されている.
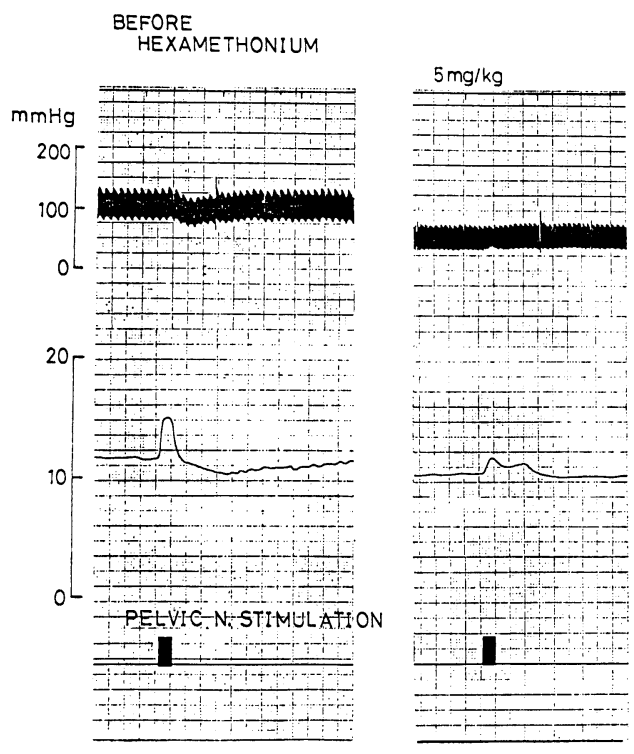

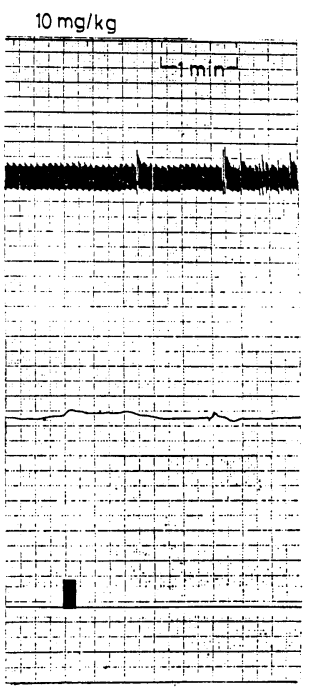

などの方法も考兄られるが，本実験では完壁を期すため に膀胱体部を切除した．第 2 点に関してはこの測定方

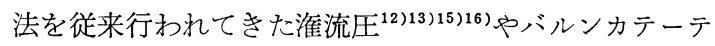
ル 1417)18) とよる測定方法と比較すると, 頝部を巾着縫合 したために特異な条件下とはなつたものの内压の変化を 定量的に示し得る点で優れていると思われる. ただ，本 実験モデルに括ける問題点を強いて挙げるなら近位尿道 全体を 1 つの内腔とすることから，横軸方向に生じる尿 道輪状筋の反応に比較して, 縱軸方向に生じる尿道縦走 筋の反応は捉兄難かつたのではないかという点である. しかし, 従来の尿道内圧測定法の場合にも尿道輪状筋の 反応を拈もに把觉る傾向があるので, 本実験モデルは現 状に沏いて妥当なるのと考党られる.

本実験では下腹括よび骨盤神経刺激に対して近位尿道 はいずれも収縮反応を呈し,さらに各種自律神経遮断剤 投与後にその収縮反応は表 3 亿まとめたような変化を示 した. 交感神経系の尿道に対する影響は平滑筋自体より そこを潅流する血管系に大きく作用するとの報告 ${ }^{17}$ があ ることから，血圧下降の著しい hexamethonium の場合 には投与後の反応が血圧の変化に続発して生じたものと 考兄られないこともない。しかし， hexamethonium 投与 後に下腹拉よび骨盤神経電気刺激に対する収縮反応は, いずれも血圧が有意に低下している条件下で別々の反応
を示した。すなわち，下腹神経電気刺激に対する収縮反 応の場合には不変であり, 一方, 骨盤神経の場合には抑 制を受けていた.このことから本実験結果は血圧の変化 に続発して生じたものではないと思われた，各薬剤の作 用部位を考えると，下腹括よび骨盤神経刺激による近位 尿道収縮反応の介する経路は，以下のようになるものと 思われる. 寸なわち，下腹神経刺激泣対する近位尿道収 縮反応が， $\alpha$ 型遮断薬により抑制され， $\beta$ 型遮断薬では 不変であり, アドレナリン作働性ニューロン遮断薬によ り抑制され，神経節遮断薬では不変であつたことから， この反応は電極装着部位より中枢側に存在する下腸間膜 動脈神経叢でニューロンをかえる long postganglionic adrenergic fiberを介する $\alpha$ 作用により生じたるのと考兄 られる．また，骨盤神経刺激に対する近位尿道収縮反応 が， $\alpha$ 型遮断薬により抑制され， $\beta$ 型遮断薬では不変で あり，アドレナリン作働性ニューロン遮断薬により抑制 され，神経節遮断薬でも抑制されたことから，この反応 は電極装着部位より末梢側のいわゆる尿道壁内神経節で ニューロンをかえて尿道に分布する short postganglionic adrenergic fiber ${ }^{122) 2021)}$ を介する $\alpha$ 作用により生じたる のと推定される.

下腹神経刺激に対する尿道反応に関しては，これまで それぞれの実験モデルや方法の違いにより，収縮反応を 
示したとする報告6)13144)，収縮相と弛緩相を有する 2 相

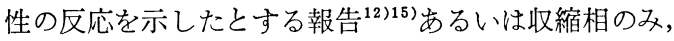
弛緩相のみ抢よび 2 相性の 3 種の反応を示したとする報 告 ${ }^{16) 18)}$ ある。、い゙れにしてもこれらの反応のらら収縮 反応は $\alpha$ 型遮断薬によつて抑制され ${ }^{13) 1415) 18)}$ ，また弛緩 反応は $\beta$ 型遮断薬により抑制され ${ }^{15) 18}$ ，神経節遮断薬で

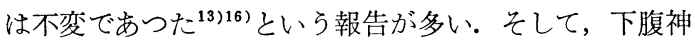
経刺激に対する近位尿道内圧反応は，刺激によりこの下 腹神経内に存在する long postganglionic adrenergic fiber の神経終末より noradrenaline が放出され，それが $\alpha$ お よび $\beta$ 受容体に働いた結果， $\alpha$ および $\beta$ 作用 の代数和 となつて表われたものとされている612) 18)。したがつ $\tau ， \alpha$ 作用が優位の場合には収縮反応として， $\beta$ 作用が 優位の場合には弛緩反応として表われることになる。し かし，本実験では下腹神経刺激に対する尿道収縮反応 が，propranolol の投与後には軽度の増強される傾向を 示し，その堌強が推計学的には不確実であつたことか ら， $\beta$ 作用が近位尿道に存在するとしてもその意義は $\alpha$ 作用と比較すれば小さなものと考兄られる。

次に, 骨盤神経刺激に対する尿道反応に関しては, これ まで収縮反応を示したとする報告 ${ }^{13) 14) 17) 18)}$ と驰緩反応を 示したとする相反する 2 種の報告 ${ }^{15) 16) か ゙ あ る か ゙ ， い す ゙ れ ~}$ にしても神経節遮断薬の投与後には投与前の反応が抑制 されている ${ }^{13) 16)}$ 。そして，骨盤神経刺激に対する近位尿 道反応は，従来，尿道壁に近接した神経節でニューロン をかえて尿道に分布する postganglionic cholinergic fiber の神経終末から放出される acetylcholine がコリン受容 体に働いた結果とする見解が多くみられる ${ }^{13) 14) 17) 18)}$ 。と ころがこれとは異なつた見解も見受けられる。たとえ ば，McGuire ${ }^{15)}$ は投与前に認められた骨盤神経刺激に よる尿道の弛緩反応が propranolol の投与により抑党 られたとし，この反応は $\beta$ 受容体を介する反応である と報告している. さらに, Girado \& Campbell16) は, 下腹神経が切断されていない場合には，骨盤神経刺激に よつて生じる尿道の弛緩反応がアドレナリン作働性神経 系から何らかの関与を受けることを示唆している。 ま た，Elbadawi \& Schenk ${ }^{122)}$ ，小柳 ${ }^{21}{ }^{11}$ 抢よび Krane \& Olsson $^{22)}$ らによれば，副交感神経節 と交感神経節との 間に介在する postganglionic cholinergic fiber が short postganglionic adrenergic fiber に対して何らかの修飾 を与えるとされている，以上から，本実験で示された骨 盤神経刺激汇対する尿道収縮反応山，副交感神経節と交 感神経節との間に介在する postganglionic cholinergic fiber を経由して, short postganglionic adrenergic fiber が刺激を受けた結果生じたものと考えることもできよ う.

さらに, Nergårdh \& Borćus ${ }^{23)}$ は猫の膀脂䅡部および尿 道摘出標本を用いた in vitro 潅流実験から尿道縦走筋 は postganglionic cholinergic fiber の作用を受け，尿道 輪状筋は short postganglionic adrenergic fiber の作用 を受けることを示唆している，解剖学的にも，尿道輪状 筋䛻内にアドレナリン作働性の神経線維拉よび神経終末 がはるかに豊富に存在するといら報告 ${ }^{5220}$ が行われてい ることから，尿道輪状筋が adrenergic fiber の支配を 受けることは注ぼ確実と思われる。したがつて，本実 験では long postganglionic aderenergic fiber に加光て short postganglionic adrenergic fiber の支配をも受ける 尿道輪状節の反応が招もに把えられていたものと考学ら れる.

犬の近位尿道が下腹神経電気刺激のみならず骨盤神経 電気刺激に対しても， adrenergic fiber を介する $\alpha$ 作用 で収縮反応を示した今回の実験結果は，近位尿道の壁緊 張維持に対する adrenergic fiber の重要性を示唆するも のである。

\section{結語}

下腹括よび骨盤神経電気刺激に対する近位尿道の反応 について，雌の雑種成犬を対象として，4種の自律神経 遮断剤 (phentolamine, propranolol, guanethidine, hexamethonium）の投与前後で検討し，以下のような結果を 得た。

1）近位尿道は $5 \mathrm{~V}, 20 \mathrm{~Hz}, 2 \mathrm{msec}$ の刺激条件， 10 秒 間の持続時間の下腹拉よび骨䯣神経電気刺激のいずれに 対しても収縮反応を示した。

2）下腹神経電気刺激に対する尿道収縮反応は，phentolamine 护よび guanethidine の投与により抑制を受 け，propranolol 拉よび hexamethonium の投与では不変 であつた。 したがつて，本実験で認められた下腹神経刺 激に対する収縮反応は，下腸間膜動脈神経叢にてニュ一 ロンをかえた long postganglionic adrenergic fiber を介 する $\alpha$ 作用により生じた反応と考兄られた.

3）骨盤神経電気刺激に対する尿道収縮反応は，phentolamine, guanethidine 㧊よび hexamethonium の投与 により抑制を受け， propranolol の投与では不変であつ た.したがつて，本実験で認められた骨盤神経刺激に対 する収縮反応は，壁内神経節でニューロンをか完て尿道 飞分布する short postganglionic adrenegic fiber を介す 
る $\alpha$ 作用により生じた反応と考学られた。

4）以上の結果より，下腹扣よび骨盤神経は近位尿道 壁の緊張を維持する上で重要な役割を果していることが 明らかになつた。

（稿を終るにあたり，御指導と御校閲を賜つた恩師土 田正義教授, ならびに御教示々御校閲を賜つた東北大学 薬理学教室第二講座平則夫教授に深甚なる謝意を表しま す. また御指導, 御助力を頂いた木村行雄講師を始め教 室諸兄に深く感謝いたします。

なお本論文の要旨は第68回日本泌尿器科学会総会およ び第20回日本平滑筋学会総会において発表した。)

\section{文献}

1) Elbadawi, A. and Schenk, E.A.: A new theory of the innervation of bladder musculature. Part 3. Postganglionic synapses in ureterovesico-urethral autonomic pathways. J. Urol., 105, 372-374, 1971.

2) Elbadawi, A. and Schenk, E.A.: A new theory of the innervation of bladder musculature. Part 4. Innervation of the vesicourethral junction and external urethral sphincter. J. Urol., 111, 613-615, 1974.

3) Gosling, J.A. and Dixon, J.S.: The structure and innervation of smooth muscle in the wall of the bladder neck and proximal urethra. Brit. J. Urol., 47, 549—558, 1975.

4) Gosling, J.A., Dixon, J.S. and Lendon, R.G.: The autonomic innervation of the human male and female bladder neck and proximal urethra. J. Urol., 118, 302-305, 1977.

5) Watanabe, J. and Yamamoto, T.: Autonomic innervation of the muscles in the wall of the bladder and proximal urethra of male rats. J. Anat., 128, 873-886, 1979.

6) Kleeman, F.J.: The physiology of the internal urinary sphincter. J. Urol., 104, 549-554, 1970.

7) Dhasmana, K.M., Gupta, G.P. and Bhargava, K.P.: Analysis of the adrenergic receptors in the urinary tract of dog. Jap. J. Pharmac., 20, 461-466, 1970.

8) Raz, S. and Caine, M.: Adrenergic receptors in the female canine urethra. Invest. Urol., 9, 319-323, 1972.

9) Raz, S., Zeigler, M. and Caine, M.: Isometric studies on canine urethral musculature. Invest. Urol., 9, 443-446, 1972.

10) Nergårdh, A.: The functional role of adrenergic receptors in the outlet region of the urinary bladder. An in vitro and in vivo study in the cat. Scand. J. Urol. Nephrol., 8, 100-107, 1974.

11) Khanna, O.P., Heber, D. and Gonick, P.: Cholinergic and adrenergic neuroreceptors in urinary tract of female dogs. Urology, $\mathbf{5}, \mathbf{6 1 6}$ 623, 1975.

12) Awad, S.A. and Downie, J.W.: The effect of adrenergic drugs and hypogastric nerve stimulation on the canine urethra. A radiologic and urethral pressure study. Invest. Urol., 13, 298-301, 1976.

13) Norlén, L.: Effects on the urinary bladder and urethra of different pharmacological treatments. An in-vivo study in normal and parasympathetically denervated cats. Scand. J. Urol. Nephrol., 11, 7-16, 1977.

14) Bruschini, H., Schmidt, R.A. and Tanagho, E.A.: The male genitourinary sphincter mechanism in the dog. Invest. Urol., 15, 284-287, 1978.

15) McGuire, E.J.: Experimental observations on the integration of bladder and urethral function. Invest. Urol., 15, 303-307, 1978.

16) Girado, J.M. and Campbell, J.B.: The innervation of the urethra of the female cat. Exp. Neurol., 1, 44-64, 1959.

17) Tanagho, E.A., Meyers, F.H. and Smith, D.R.: Urethral resistance: Its components and implications. I. Smooth muscle component. Invest. Urol., 7, 136-149, 1969.

18) Graber, P. and Tanahgo, E.A.: Urethral responses to autonomic nerve stimulation. Urology, 6, 52-58, 1975.

19) De Sy, W., Lacroix, E. and Leusen, I.: An analysis of the urinary bladder response to hypogastric nerve stimulation in the cat. Invest. Urol., 11, 508-516, 1976.

20) Owman, Ch., Owman, T. and Sjöberg, N.O.: Short adrenergic neurons innervating the female urethra of the cat. Experientia, 27, 313-315, 1971.

21) 小柳知彦: 神経因性膀胱飞打计る尿道の denervation supersensitivity 反応．日泌尿会誌，69, 893-901, 1978.

22) Krane, R.J. and Olsson, C.A.: Phenoxybenzamine in neurogenic bladder dysfunction. I. A theory of micturition. J. Urol., 110, 650 652, 1973.

23) Nergårdh, A. and Boréus, L.O.: The functional role of cholinergic receptors in the outlet region of the urinary bladder: An in vitro study in the cat. Acta Pharmacol. et Toxicol., 32, 467-480, 1973.

（1980年 4 月 12 日受付） 